\title{
In vitro progesterone production by luteinized human mural granulosa cells is modulated by activation of AMPK and cause of infertility
}

\author{
E. C. Bowdridge ${ }^{2^{*}}$, M. W. Vernon ${ }^{3}$, J. A. Flores ${ }^{1}$ and M. J. Clemmer ${ }^{3}$
}

\begin{abstract}
Background: Mural granulosa cells from IVF patients were provided by the West Virginia University Center for Reproductive Medicine in Morgantown, WV. The effect of adenosine monophosphate activated protein kinase (AMPK) activation, primary cause of infertility, age, BMI, and pregnancy outcome on production of progesterone were examined separately.

Methods: Isolated mural sheets from IVF patients $(n=26)$ were centrifuged, supernatant discarded, and the pellet re-suspended in $500 \mu \mathrm{l}$ of DMEM/F12. Mural granulosa cells were plated at 10,000 cells/well in triplicate per treatment group with $300 \mathrm{\mu l}$ DMEM/F12 media at $37^{\circ} \mathrm{C}$ and $5 \%$ CO2 in a humidified incubator to permit luteinization. Four days after initial plating, cells were treated with either an AMPK inhibitor, DM; an AMPK activator, AICAR; or hCG. Cells were cultured for $24 \mathrm{~h}$ after treatment when medium was collected and frozen at $-20{ }^{\circ} \mathrm{C}$ until assayed for P4 by radioimmunoassay.

Results: The AMPK activator, AICAR, inhibited P4 production $(P<0.001)$, whereas the AMPK inhibitor, DM, did not affect basal P4 $(P<0.05)$. Progesterone production increased when cells from patients whose primary cause of infertility was a partner having male infertility were treated with hCG compared to control $(P=0.0045)$, but not in patients with other primary infertility factors $(P>0.05)$. Additionally, hCG increased P4 production in patients between the ages 30-35 ( $P=0.008)$ and 36-39 $(P=0.04)$, but not in patients ages 25-29 $(P=0.73)$. Patients with normal BMl had increased P4 production when treated with hCG $(P<0.0001)$, however there was no change in P4 production from cells of patients who were overweight or obese $(P>0.05)$. Cells from patients who became pregnant to IVF had greater P4 production when stimulated with hCG than those who did not become pregnant when compared to controls $(P>0.05)$.

Conclusions: Understanding how AMPK activation is regulated in ovarian cells could lead to alternative or novel infertility treatments. Human mural granulosa cells can serve as a valuable model for understanding how AMPK affects P4 production in steroidogenic cells. Additionally, when stimulated with hCG, P4 production by mural granulosa cells differed among infertility type, age, BMI, and pregnancy outcome.
\end{abstract}

Keywords: Granulosa cells, Pregnancy, Luteal insufficiency

\footnotetext{
* Correspondence: ebowdrid@hsc.wvu.edu

2Department of Physiology and Pharmacology, West Virginia University, P.O.

Box 4992, Morgantown, WV 26506, USA

Full list of author information is available at the end of the article
} 


\section{Background}

Two distinct populations of granulosa cells exist within the ovulatory follicle, the mural granulosa cells that line the follicle and the cumulus granulosa cells that surround the oocyte. After ovulation, mural granulosa cells remain in the follicle while cumulus granulosa cells are expelled from the follicle with the oocyte [19]. The mural granulosa cells that remain in the ovulatory follicle lose their ability to proliferate and to produce estradiol. Under the influence of the LH surge which induced the ovulation, the mural cells undergo an epithelial-mesenchymal transition that leads to the formation of the large luteal cells (LLC) of the corpus luteum [CL], which secrete high amounts of progesterone [P4] [6]. In the presence of human chorionic gonadotropin $[\mathrm{hCG}]$ from a conceptus, the $\mathrm{CL}$ is rescued from luteolysis and maintains its production of $\mathrm{P} 4$, which is essential for the maintenance of pregnancy. Insufficient luteal rescue may lead to decreased $\mathrm{P} 4$ production that can lead to pregnancy loss. Luteal insufficiency has been estimated to be as high as $28 \%$ in couples with recurrent pregnancy loss $[14,15]$. A better understanding of insufficient luteal rescue could improve the clinical diagnosis and treatment of early pregnancy loss.

In multiple species, sufficient energy is required for P4 production $[23,24]$. Adenosine monophosphate activated protein kinase [AMPK] is a key regulatory protein for energy balance, and activation of AMPK results in a shift from anabolic to catabolic processes [11]. In rat granulosa cells, P4 was directly inhibited by AMPK activation [25]. Various subunits of AMPK have also been identified in the granulosa cells of small and large bovine follicles [23]. 5-Aminoimidazole-4-carboxamide$1-\beta$-4-ribofuranoside [AICAR] is a well-established, cell-permeable agent, which both directly activates AMPK alloterically and promotes phosphorylation of AMPK [7]. Treatment with AICAR $(7.5 \mathrm{mM})$ significantly decreased basal $\mathrm{P} 4$ production in bovine CL in vitro [4]. In contrast, dorsomorphin dihydrochloride (DM) is a potent, selective, cell-permeable and reversible AMPK inhibitor [17]. Treatment with DM inhibited AMPK activation induced by AICAR [22] or metformin [12].

The objectives of this project were to investigate the role of AMPK, a known intracellular mediator of energy balance, and a patient's primary cause of infertility on the production of $\mathrm{P} 4$ in luteinized human granulosa cells.

\section{Methods}

\section{Patients}

Mural and cumulus granulosa cells from patients $(n=26)$ undergoing egg retrieval after ovarian stimulation for in vitro fertilization [IVF] were provided by the WVU Center for Reproductive Medicine in Morgantown from April to December 2012. The age, BMI and primary cause of infertility were random as all patients with granulosa cells collected at oocyte retrieval were included in the study. Primary cause of infertility was assigned based on severity of the problem contributing most to preventing a successful pregnancy for each patient, with preference given to any issues with the female. Any endocrine related factor, such as endometriosis, was prioritized as the primary cause of infertility over any anatomical factor, such as tubal blockage, because these types of endocrine conditions were more likely to affect the granulosa cells collected for experiments. Patients were designated as male factor patients if there were no indications of female infertility and the male partner presented with an abnormal semen evaluation.

Daily or twice-daily injections of recombinant follicle stimulating hormone [FSH] began on $\mathrm{d} 2$ or $\mathrm{d} 3$ of the cycle and continued until ovulation was induced with hCG. One of the following preparations of FSH was used: Bravelle (Ferring Pharmaceuticals, Parsippany, NJ), Gonal F (EMD Serono, Rockland, MD), or Follistim (Merck, Whitehouse Station, NJ) in addition to Menopur (Ferring Pharmaceuticals Inc. Parsippany, NJ), which was used for every patient. Patients returned at least every other day for sonographic and hormonal monitoring of follicular growth beginning four days after initiation of stimulation. To prevent premature ovulation, gonadotropin releasing hormones [GnRH] antagonist injections (Ganirelix, Merck, Kenilworth, NJ) began when follicles reached at least $14 \mathrm{~mm}$ in diameter. Ovulation was induced with hCG injection (10,000 IU; Novarel, Ferring Pharmaceuticals, Parsippany, NJ) when at least two follicles were $\geq 18 \mathrm{~mm}$ in diameter, followed by oocyte collection $34 \mathrm{~h}$ later.

\section{Isolation and culture of primary human GCs}

Sheets of mural granulosa cells were distinguished by anatomical structure and manually separated from cumulus granulosa cells by experienced embryologists following oocyte retrieval. Isolated mural sheets from each patient in G-MOPS Plus media (Vitrolife, Göteborg, Sweden) were centrifuged at 10,000 rpm for $5 \mathrm{~min}$ at room temperature. Supernatant was discarded, and the pellet was re-suspended in $500 \mu \mathrm{l}$ of DMEM/F12 (Invitrogen, Grand Island, NY) with $20 \%(\mathrm{v} / \mathrm{v})$ fetal bovine serum, insulin/transferrin/ selenium B (1000; 555; $0.67 \mathrm{mg} / \mathrm{L}$ respectively; Gibco, Grand Island, NY), gentamicin/amphotericin $(10 \mu \mathrm{g} / \mathrm{ml}-$ $0.25 \mu \mathrm{g} / \mathrm{ml}$; Gibco, Grand Island, NY), and penicillin/streptomyocin (100 I.U./ml, $100 \mu \mathrm{g} / \mathrm{ml}$; Life Technologies, Grand Island, NY). Viable cell number was determined using trypan blue dye exclusion (Gibco, Grand Island, NY) and a hemocytometer. All patients had cell viability $>90 \%$ and cells were plated at 10,000 cells per well in 96-well flat bottom culture plates with $300 \mu \mathrm{l}$ DMEM/F12 media (NUNC, Scientific Laboratory Supplies, Wilford, Nottingham, UK) at $37{ }^{\circ} \mathrm{C}$ and $5 \% \mathrm{CO}_{2}$ in a humidified incubator to permit luteinization and cell attachment. Media was changed every 
$24 \mathrm{~h}$ whereby $150 \mu \mathrm{l}$ of spent media was replaced with fresh DMEM/F12 plus serum. Peak progesterone levels in human mural granulosa cells have been shown to occur on day 4 of culture [1], as was the case during preliminary testing of our culture conditions of days of luteinization ranging from 1 to 7 (data not shown), and therefore used as the experimental day. Four days after collection, cells were transferred to serum free DMEM/F12 media, and treatments were administered. Every treatment was tested in triplicate for each patient and media pooled for P4 by radioimmunoassay [RIA] as previously described [20]. Control values for each patient were obtained by culturing cells in triplicate with no hormones. This basal progesterone production, which was obtained on the same day as treatments, was used as a baseline for each patient, and treatments with pharmacological agents or hormones were compared to baseline within patient.

\section{Experiment 1}

Treatments were based on previous studies in bovine luteal steroidogenic cells [3] and mural granulosa cells. The medium for the control group contained $0.1 \%$ dimethylsufoxide (DMSO, Pierce Rockport, IL), the solvent used for DM and AICAR. Mural granulosa cells isolated from patients presenting with tubal or male factor infertility were used in experiment 1 to control for any confounding female endocrine effect. Mural granulosa cells were treated with DM $(109,10.9,1.09,0.109 \mu \mathrm{m} / \mathrm{L}$, Tocris, Bristol, UK) or AICAR (7.5, 0.75, 0.075, $0.0075 \mathrm{mM}$, Tocris, Bristol, UK) to evaluate the roles of inhibiting or stimulating AMPK, respectively, in luteinized mural granulosa cell production of P4. Cells were cultured for $24 \mathrm{~h}$ and medium was removed and frozen at $-20{ }^{\circ} \mathrm{C}$ until assayed for $\mathrm{P} 4$.

\section{Experiment 2}

Cells were treated with $\mathrm{PGF}_{2 \alpha}(0.1 \mu \mathrm{g} / \mathrm{ml}$; Cayman Chemical, Ann Arbor, MI), or human hCG (5 IU/ml; Novarel, Ferring Pharmaceuticals, Parsippany, NJ), or the combination of the two $\left(\mathrm{PGF}_{2 \alpha}+\mathrm{hCG}\right)$. Treatment concentrations of $\mathrm{PGF}_{2 \alpha}$, hCG, or $\mathrm{PGF}_{2 \alpha}+\mathrm{hCG}$ and incubation times were based on previous studies with bovine luteal steroidogenic cells [3] and preliminary studies testing 24, 48, and $96 \mathrm{~h}$ incubation times in mural granulosa cells, respectively. Cells were cultured further for $24 \mathrm{~h}$ after treatment at which time medium was removed and frozen at $-20{ }^{\circ} \mathrm{C}$ until assayed for $\mathrm{P} 4$. Main cause of infertility (male factor, endometriosis, tubal factor, and unexplained), age $(<30,30-35$, $36-39$ years of age), BMI (normal $=18.5-24.9$, overweight $=25-29.9$, obese $\geq 30$ ), and pregnancy outcome (non-pregnant and pregnant) were analyzed.

\section{Statistical analysis}

Concentrations of $\mathrm{P} 4$ were tested for normal distribution via the Shapiro-Wilk test. All data were transformed using natural logarithm. All other experiments were analyzed using one-way ANOVA and Dunnett's post hoc test. Data were analyzed using JMP and SAS software (JMP ${ }^{\circ}$, Version Pro 11, SAS Institute Inc., Cary, NC, Copyright @2013; SAS ${ }^{\circ}$, Version 9.3, SAS Institute Inc., Cary, NC, Copyright @2002-2010). Differences were considered significant when $P<0.05$. Data throughout are depicted as the mean \pm SE.

\section{Results}

\section{General patient information}

Patients presented randomly with the following as their main cause of infertility: male factor $(n=5)$, endometriosis $(n=6)$, tubal factor $(n=12 ; n=11$ naturally occurring tubal issues and $\mathrm{n}=1$ tubal ligation), and other/unexplained $(n=3)$. They ranged in age from 25 to 39 years of age (mean age $33.0 \pm 0.70$ ) and were classified as $<30$ $(n=4), 31-35(n=15)$, or $\geq 36(n=7)$. Patients had a BMI range of 18.9 to 44.3 (mean BMI $25.0 \pm 1.1$ ) and were classified as normal 18.5-24.9 $(n=17)$, overweight $25-$ $29.9(n=6)$ or obese $\geq 30.0(n=3)$. Most patients $(n=13)$ were pregnant after the IVF cycle was completed; 10 did not become pregnant and the remaining patients $(n=3 ; 1$ no fertilization and 2 planned embryo cryopreservation) did not receive a fresh embryo transfer at the end of the IVF cycle. Information about the general response of these patients to stimulation and IVF are recorded in Table 1.

\section{Experiment 1}

To more deeply understand production of progesterone in luteinized granulosa cells, the pathway involved in

Table 1 General patient information

\begin{tabular}{llll}
\hline Patient Information & $\mathrm{n}$ & Range & Mean \\
\hline Age & 26 & $25-39$ & $33 \pm 3.58$ \\
BMI & 26 & $19-36$ & $24.96 \pm 5.50$ \\
Gravidity & 26 & $0-9$ & $1.42 \pm 2.44$ \\
Total Gonadotropins (IU) & 26 & $450-4200$ & $1613 \pm 899$ \\
Stimulation Days & 26 & $7-12$ & $9.19 \pm 1.20$ \\
Day 3 FSH (mIU/mL) & 20 & $4-13$ & $7.32 \pm 2.16$ \\
E2 at trigger $(\mathrm{pg} / \mathrm{mL})$ & 26 & $364-3669$ & $1678 \pm 837$ \\
P4 at trigger $(\mathrm{ng} / \mathrm{mL})$ & 26 & $0.43-2.63$ & $1.13 \pm 0.68$ \\
Total oocytes retrieved & 26 & $2-23$ & $8.4 \pm 4.7$ \\
MII oocytes retrieved & 26 & $2-18$ & $6.5 \pm 3.8$ \\
Fertilization rate $(\%)$ & 26 & $0-100$ & $82.6 \pm 24.5$ \\
Division rate $(\%)$ & 26 & $67-100$ & $95.8 \pm 8.8$ \\
\hline
\end{tabular}

Ranges and means for gravidity, stimulation, hormonal profiles, oocytes retrieved during the IVF cycle, fertilization rate of MII oocytes, and division rate of fertilized oocytes 
energy regulation was manipulated. The AMPK activator, AICAR, inhibited P4 production by human luteinized mural granulosa cells at all dosages tested $(P<0.001$; Fig. 1a). In Fig. 1b, the AMPK inhibitor, DM, did not affect basal progesterone production $(P<0.05)$.

\section{Experiment 2}

Within cause of infertilty, no significant differences in $\mathrm{P} 4$ were seen when granulosa cells were treated with $\mathrm{PGF}_{2 \alpha}$ or $\mathrm{PGF}_{2 \alpha}+$ hCG in any infertility types (data not shown), with the exception of male infertility, (control $\mathrm{P} 4=0.77 \pm 0.24 \mathrm{ng} / \mathrm{ml}$ vs. $\mathrm{GF}_{2 \alpha}=1.56 \pm 0.68 \mathrm{ng} / \mathrm{ml}$; $P<0.05)$ Additionally, no significant differences in P4 were seen when granulosa cells were treated with $\mathrm{PGF}_{2 \alpha}$ or $\mathrm{PGF}_{2 \alpha}+$ hCG in any age or BMI category, or pregnancy outcome (data not shown).

There was an increase in $\mathrm{P} 4$ production over baseline in cells treated with hCG and collected from patients that presented with no known female/male infertility factor $(0.77 \pm 0.24 \mathrm{ng} / \mathrm{ml}$ vs. $2.49 \pm 0.38 \mathrm{ng} / \mathrm{ml} ; P=0.0045$; Fig. 2), but not in patients who presented with endometriosis $(1.91 \pm 0.87 \mathrm{ng} / \mathrm{ml}$ vs. $2.23 \pm 1.2 \mathrm{ng} / \mathrm{ml})$, other/unexplained $(1.19 \pm 0.80 \mathrm{ng} / \mathrm{ml}$ vs. $2.23 \pm 0.93 \mathrm{ng} /$ $\mathrm{ml})$ or tubal factor $(1.30 \pm 0.36 \mathrm{ng} / \mathrm{ml}$ vs. $2.10 \pm 0.46 \mathrm{ng} / \mathrm{ml}$; $P>0.05$; Fig. 2).

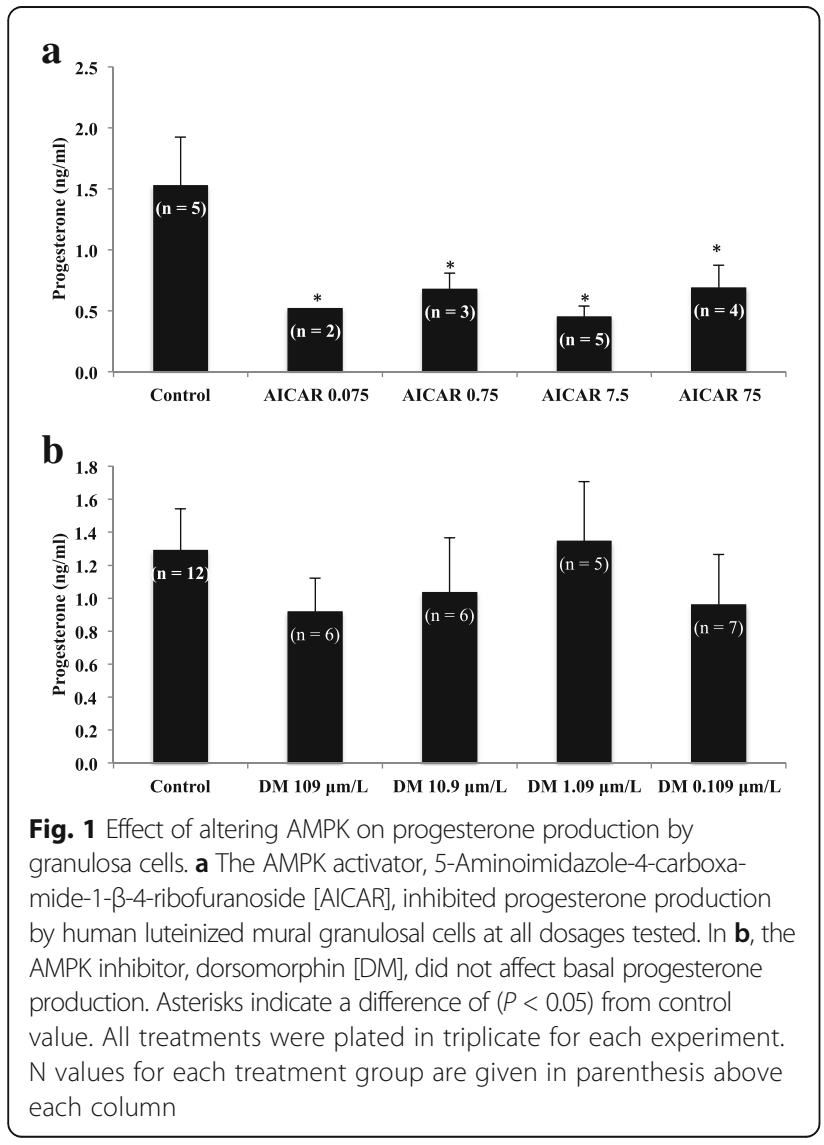

Additionally, patient age influenced the ability of hCG to stimulate a significant increase in P4. Production of P4 increased following treatment with hCG for patients in the age range of $30-35(1.23 \pm 0.40 \mathrm{ng} / \mathrm{ml}$ vs. $2.03 \pm 0.46 \mathrm{ng} / \mathrm{ml} ; P=0.008)$ and $36-39(n=7$; $1.41 \pm 0.45 \mathrm{ng} / \mathrm{ml}$ vs. $2.37 \pm 0.53 \mathrm{ng} / \mathrm{ml} ; P=0.04)$, but not in patients in the ranges of 25-29 $(n=4$; $1.52 \pm 0.75 \mathrm{ng} / \mathrm{ml}$ vs. $2.65 \pm 0.91 \mathrm{ng} / \mathrm{ml} ; P=0.73$; Fig. 3 ).

Patients with normal BMI had a significant increase in P4 production when treated with hCG $(1.29 \pm 0.34 \mathrm{ng} / \mathrm{ml}$ vs. $2.25 \pm 0.46 \mathrm{ng} / \mathrm{ml} ; P<0.0001$; Fig. 4 ), but granulosa cells of patients who were categorized as overweight or obese did not have a significant increase in $\mathrm{P} 4$ production when stimulated with hCG $(1.85 \pm 0.63 \mathrm{ng} / \mathrm{ml}$ vs. $2.61 \pm 0.46 \mathrm{ng} /$ $\mathrm{ml}$ and $0.50 \pm 0.18 \mathrm{ng} / \mathrm{ml}$ vs. $1.24 \pm 0.45 \mathrm{ng} / \mathrm{ml}$, respectively; $P>0.05$; Fig. 4 ).

Figure 5 demonstrates that granulosa cells from patients who became pregnant to the IVF cycle had significantly increased $\mathrm{P} 4$ production compared to controls when stimulated with hCG $(2.4 \pm 0.37 \mathrm{ng} / \mathrm{ml} ; P=0.0018$ vs. control; Fig. 4) whereas those who did not become pregnant did not $(1.8 \pm 0.58 \mathrm{ng} / \mathrm{ml} ; P>0.05$ vs. control; Fig. 5$)$.

\section{Discussion}

Activation of AMPK, a key regulator of energy homeostasis, decreased basal P4 production in bovine [23] and rodent [25] granulosa cells, whereas AMPK increased P4 in galline [24] granulosa cells. In agreement with the findings in cattle and rats, treatment with AICAR resulted in a significant decrease in basal $\mathrm{P} 4$ at all concentrations tested in experiment 1. Similarly, AICAR treatment resulted in a decrease in P4 production in the mature bovine CL [4]. This decrease in $\mathrm{P} 4$ could be explained, at least in part, by a decrease in key enzymes such as $3 \beta \mathrm{HSD}$, P450scc, or StAR, all of which have been shown to be decreased after treatment with AICAR in rat granulosa cells [25]. These experiments show that the AMPK pathway is inhibitory to basal $\mathrm{P} 4$ production in luteinized human granulosa cells in the early stage of luteinization and presumably even more so with further luteal maturation.

In contrast to the effect of AMPK activation, no difference in P4 production were seen when mural cells were treated with an AMPK inhibitor, DM. The concentrations of DM chosen for Experiment 1 were based on studies in bovine $\mathrm{CL}$, in which DM significantly decreased $\mathrm{P} 4$ production following stimulation with $\mathrm{PGF}_{2 \alpha}$ (Bowdridge, unpublished results). However, a greater concentration of DM may be needed to elicit a change in basal $\mathrm{P} 4$ production in human mural granulosa cells. Additionally, because DM is an AMPK inhibitor cells may need to first be stimulated with hCG, $\mathrm{PGF}_{2 \alpha}$, or another AMPK activator prior to DM treatment in order to see a reduction in $\mathrm{P} 4$ production. Due to the limited number of granulosa cells that are collected from each patient, these experiments were unable to 


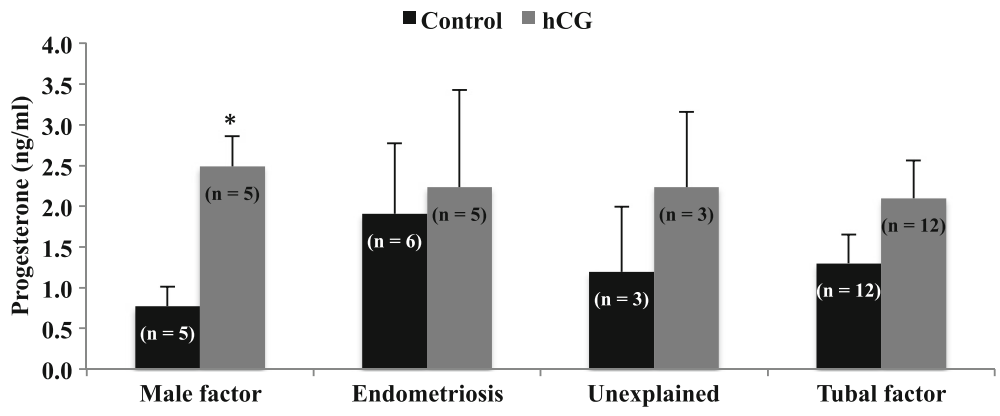

Fig. 2 Progesterone production by granulosa cells from patients with different causes of infertility. Progesterone production by granulosa cells from patients with male factor, endometriosis, other/unexplained, and tubal infertility before and after treatment with PGF $2 a(0.1 \mu \mathrm{g} / \mathrm{ml})$ or hCG $(5 \mathrm{IU} / \mathrm{ml})$. Asterisks indicate a difference of $(P<0.05)$ from control value within infertility group. $N$ values for each treatment group are given in parenthesis above each column

be performed simultaneously. It is also possible that the effect of inhibition of AMPK in granulosa cells differs between species such as cattle and humans, much the same way as AMPK activation increases P4 in the chicken, but not in rats or chickens. Therefore, it appears that stimulated, but not basal P4 secretion, is regulated by AMPK in human mural granulosa cells.

Data from Experiment 2 support the conclusion that infertility type affects the ability of luteinized human mural granulosa cells to respond in vitro to the luteotropic factor, hCG. If these cells likewise failed to respond to hCG in vivo it could lead to luteal insufficiency or even early regression of the $\mathrm{CL}$, resulting in pregnancy loss. Our hypothesis is that the in vivo environments in which granulosa cells develop contribute to their ability to respond to hCG as they transition into a luteal phenotype. Progesterone production after stimulation with hCG in granulosa cells from endometriosis, unexplained, and tubal factor patients was not different than basal P4 production. Therefore, these patients were unable to respond to stimulation by hCG, despite having normal basal P4 levels. However, as expected, granulosa cells from patients with partners having male infertility exhibited a significant increase in $\mathrm{P} 4$ production when compared to control values. Clinically, all patients undergoing IVF treatments are regularly given empirical supportive P4 after embryo transfer, which eliminates the need for the patient's granulosa cells to increase $\mathrm{P} 4$ in response to embryo derived hCG to sustain a pregnancy. However, using mural granulosa cells to identify each patient's ability to naturally respond to hCG could allow for administration of lower levels of exogenous $\mathrm{P} 4$. There is recent evidence that supplemental P4 after the first positive $\beta$-hCG pregnancy test following IVF may not be necessary to achieve a live birth [16]. Elimination of unnecessary P4 supplementation could reduce cost and time requirements for patients undergoing IVF.

A significant increase in P4 was seen in mural cells of those women who became pregnant following IVF. In contrast, P4 production in the hCG-stimulated treatment group was not different from controls in the mural cells of women who did not become pregnant following IVF. Failure of these cells to secrete high levels of P4 in vivo is similar to a condition known as luteal phase defect [LPD]. In LPD there is only a brief elevation in P4 secretion (typically $<11$ days) after ovulation, and LPD is reported to occur in up to $20 \%$ of women [2]. The mean peak P4 level for women with short luteal phases was

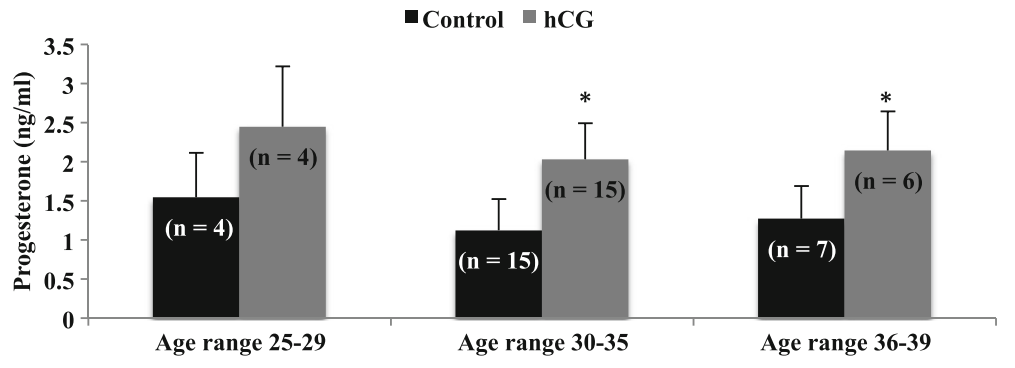

Fig. 3 Progesterone production by granulosa cells from patients of different ages. Patients who ranged in age from 25 to 29 years old did not response to hCG with a significant increase in progesterone production. However, other age groups (30-35 and $\geq 36$ years old) did have a significant increase in progesterone when stimulated with hCG. Asterisks indicate a difference of $(P<0.05)$ from control value within age ranges. Cells were treated with $\mathrm{PGF}_{2 a}(0.1 \mathrm{\mu g} / \mathrm{ml})$ or $\mathrm{hCG}(5 \mathrm{IU} / \mathrm{ml})$. N values for each treatment group are given in parenthesis above each column 


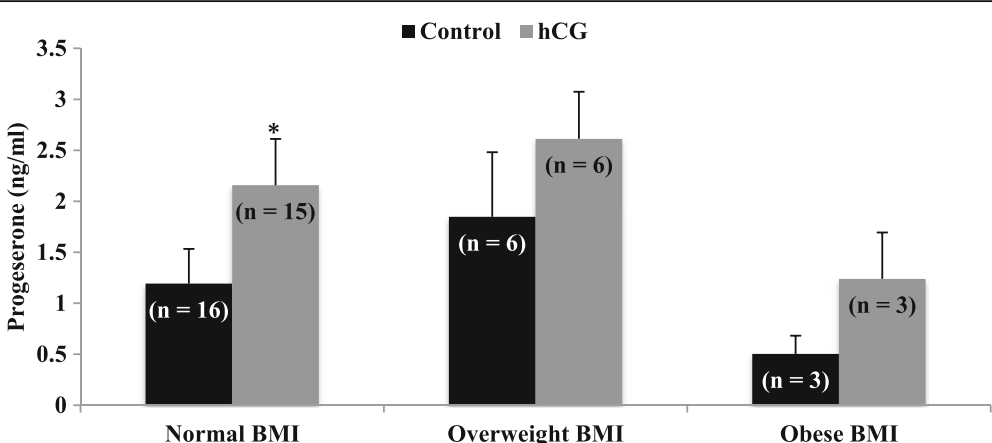

Fig. 4 Progesterone production by granulosa cells from patients with different body mass indexes. Patients with normal body mass index [BMI] (18.5-24.9) had a significant increase in progesterone production when treated with hCG $(P<0.0001)$. Cells of patients who were categorized as overweight (BMI 25-29.9) or obese (BMI $>30$ ) did not have an increase in progesterone production when stimulated with hCG $(P>0.05)$. Asterisks indicate a difference of $(P<0.05)$ from control value with BMl categories. Cells were treated with PGF $2 a(0.1 \mu \mathrm{g} / \mathrm{ml}) \mathrm{or} \mathrm{hCG}(5 \mathrm{IU} / \mathrm{ml})$. $\mathrm{N}$ values for each treatment group are given in parenthesis above each column

$1.8 \mathrm{ng} / \mathrm{ml}$ compared to the mean peak P4 level of $7.6 \mathrm{ng} / \mathrm{ml}$ for women with normal luteal phase length [21]. Interestingly, LPD has been associated with endometriosis [8], polycystic ovarian syndrome [PCOS], obesity [10], and aging [18]. These conditions differ significantly in their etiology, however all have the potential to influence the hormonal environment in which granulosa cells develop and their ability to function as luteal cells. A short luteal phase may be due to a defect in the process of luteinization or P4 production, or both. Experiments 1 and 2 were performed prior to any luteal phase supplementation in these patients, and therefore the $\mathrm{P} 4$ production would be a representation of their innate ability to respond to physiological doses of hCG. The inability of these cells to respond could potentially be explained by impaired cholesterol transport mechanisms within the ovary, or a deficiency in LH receptors. In addition, gene expression for STAR, CYP11A1, and 3ßHSD were all significantly reduced in ewes that exhibited a short luteal phase during the nonbreeding season [5]. Stimulation of mural granulosa cells with hCG and measurement of P4 levels on day 4 of culture, prior to day 5-6 blastocyst transfers, would determine if hCG response was predictive of pregnancy success independent of embryo quality.

It was not surprising that $\mathrm{P} 4$ production by mural granulosa cells was affected by age and BMI, both of which have previously been shown to alter steroid production in vivo $[9,26]$. Surprisingly, the age group that did not have an increase in P4 production was the youngest age group. It should be noted, however, that this group had the largest numerical increase in P4 when stimulated with hCG. However, the fact that granulosa cells from two of the four patients responded which lead to highly variability, several different causes of infertility (two tubal factor, endometriosis, male) and the small population size $(n=4)$ could separately or collectively account for the lack of difference within this age group. In contrast, it was encouraging to see that mural cells from older patients responded to luteotropic hCG, suggesting that these cells are capable of increases in P4, which are needed for a successful pregnancy.

- Control $\square \mathrm{hCG}$

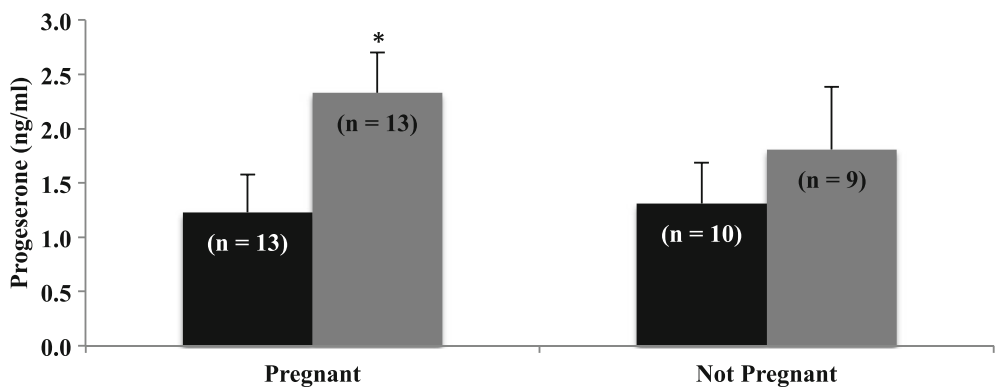

Fig. 5 Progesterone production by granulosa cells in non-pregnant versus pregnant patients. Progesterone production in mural granulosal cells was affected by pregnancy status post in-vitro fertilization (IVF). Luteinized mural granulosa cells from patients who became pregnant to the IVF cycle produced significantly more progesterone when stimulated with hCG than those who did not become pregnant $(2.4 \mathrm{vs} .1 .8 \mathrm{ng} / \mathrm{ml}$;

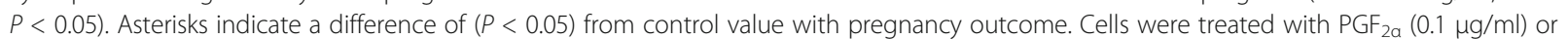
hCG $(5 \mathrm{IU} / \mathrm{ml})$. N values for each treatment group are given in parenthesis above each column 
Patients with BMIs in either the overweight or obese range did not respond to hCG with increased P4 production. However, due to the small patient number in the overweight $(n=6)$ and obese groups $(n=3)$ these results should be interpreted cautiously. Nonetheless, combining the data from these two groups to increase patient number still did not result in a significant increase in hCG stimulated P4 production $(p=0.11)$. The interrelationship between nutritional status and reproduction is complicated, and the mechanisms connecting the two are not well defined. It will be critical to ascertain if the mural cells of overweight and obese patients have insufficient substrate to produce $\mathrm{P} 4$ when stimulated or if they are resistant to hCG despite adequate substrate. In a recent study using non-human primates, weight gain directly impaired P4-secretion, which was accompanied by decreased mRNA expression for $\mathrm{LH}$ receptor, P450scc, STAR and 3BHSD within the CL, suggesting that obesity can directly affect CL function [13].

\section{Conclusions}

In summary, understanding how drugs such as AICAR, DM, and other AMPK activators alter steroidogenic pathways in ovarian cells could lead to alternative or novel infertility treatments. Human mural granulosa cells serve as a valuable model for understanding how AMPK and its downstream targets affect $\mathrm{P} 4$ production in steroidogenic cells. Additionally, when stimulated with hCG, P4 production by mural granulosa cells differed among main infertility type, age, BMI, and pregnancy outcome. Investigating differences in basal and stimulated P4 concentrations amongst such patients may also give insight into luteal steroidogenesis in an infertile population. In addition to basal and stimulated P4 production, mRNA and protein levels of key enzymes such as P450scc, StAR, and 3ßHSD should be evaluated across age, BMI, pregnancy outcome, and infertility type. Critically evaluating similarities and differences in granulosa cell $\mathrm{P} 4$ production between the previously mentioned factors has the potential to increase successful fullterm gestations in patients undergoing IVF, and decrease the incidence of miscarriages induced by luteal insufficiency.

\section{Additional file}

Additional file 1: Progestereone data from experiments 1 and 2 . (XLSX $16 \mathrm{~kb}$ )

\footnotetext{
Abbreviations

3ßHSD: 3-Beta-Hydroxysteroid Dehydrogenase; AICAR: 5-Aminoimidazole-4carboxamide-1- $\beta$-4-ribofuranoside; AMPK: Adenonsine monophosphate activated protein kinase; BMI: Body mass index; $\mathrm{CL}$ : Corpus luteum; DM: Dorsomorphin; DOR: Diminished ovarian reserve; FSH: Follicle stimulating hormone; GnRH: Gonadotropin releasing hormone; hCG: Human chorionic gonadotropin; IRB: Institutional Review Board; IVF: In-vitro fertilization; LH: Luteinizing hormone; LPD: Luteal phase defect; P4: Progesterone; P450scc: Cholesterol side chain cleavage enzyme;
}

PCOS: Polycystic ovarian syndrome; RIA: Radioimmunoassay; StAR: Steroidogenic acute regulatory protein

\section{Acknowledgements}

The authors would like to thank Dr. Ida Holásková for her assistance with the statistical analysis, and are grateful to Dr. Bob Dailey and Dr. Stan Hileman for their comments on the manuscript.

\section{Funding}

Supported by Agriculture and Food Research Initiative Competitive Grant no. 2010-65,203-20,660 from USDA National Institute of Food and Agriculture to J. F. and the West Virginia Agricultural and Forestry Experiment Station (Hatch 476, NE 1227). E. B. was supported in part by the Jerry R. Brooks fellowship in reproductive physiology.

Availability of data and materials

All datasets on which the conclusions of the paper rely are available to readers in the Additional file 1.

\section{Authors' contributions}

E.B. wrote the manuscript, and performed the experiments. M.C. and M.V. collected the cells from patients at the WVU-CRM. J.F. contributed to experimental design. All authors approved the final submitted version of the article.

\section{Ethics approval and consent to participate}

Granulosa cells were collected during routine oocyte collection procedures by two experienced embryologist (M.C. and M.V.) at the WVU Center for Reproductive Medicine. Cells were then picked up by the experimenters (E.B. and J.F.) and taken back to the Department of Biology laboratory where the experiments described were performed. Due to the fact that the experimenters were utilizing otherwise discarded materials, had no direct contact with the patient, and were not privy to any identifying information for each patient, this project was declared to be exempt by the Institutional Review Board (IRB) at West Virginia University.

\section{Consent for publication}

Not applicable.

\section{Competing interests}

The authors declare that they have no competing interests.

\section{Publisher's Note}

Springer Nature remains neutral with regard to jurisdictional claims in published maps and institutional affiliations.

\section{Author details}

${ }^{1}$ Department of Biology West Virginia University, Morgantown, W 26505, USA. ${ }^{2}$ Department of Physiology and Pharmacology, West Virginia University, P.O. Box 4992, Morgantown, WV 26506, USA. ${ }^{3}$ Department of Obstetrics and Gynecology, West Virginia University, Morgantown, WV 26506, USA.

Received: 30 May 2017 Accepted: 13 September 2017

Published online: 22 September 2017

References

1. Alexopoulos E, Shahid J, Ongley HZ, Richardson MC. Luteinized human granulosa cells are associated with endogenous basement membrane-like components in culture Mol. Hum. Reprod. 2000;6(4):324-30.

2. Balasch J, Vanrell JA. Corpus luteum insufciency and fertility: a matter of controversy. Hum. Reprod. 1987;2:557-67.

3. Bowdridge EC, Flores JA, Inskeep EK. Is AMPK required to mediate the steroidogenic actions of PGF2a in bovine corpus luteum? Biol Reprod. 2012:87:172-2.

4. Bowdridge EC, Goravanahally MP, Inskeep EK, Flores JA. Activation of adenosine monophosphate-activated protein kinase is an additional mechanism that participates in mediating inhibitory actions of prostaglandin F2Alpha in mature, but not developing Bovine Corpora Lutea. Biol Reprod. 2015;93(1):7.

5. Brown HM, Nys CF, Cognié J, Scaramuzzi RJ. Short oestrous cycles in sheep during anoestrus involve defects in progesterone biosynthesis and luteal neovascularisation. Reproduction. 2014;147(3):357-367. 
6. Chaffkin $L M$, Luciano AA, Peluso JJ. Progesterone as an autocrine/paracrine regulator of human granulosa cell proliferation. J Clin Endocrinol Metab. 1992;75:1404-8.

7. Corton JM, Gillespie JG, Hawley SA, Hardie DG. 5-Aminoimidazole-4Carboxamide Ribonucleoside. Eur J Biochem. 1995;229:558-65.

8. Cunha-Filho JS, Gross JL, Bastos de Souza CA, Lemos NA, Giugliani C, Freitas F, et al. Physiopathological aspects of corpus luteum deficiency in infertile patients with mild/minimal endometriosis. J Assist Reprod Genet. 2003;20:117-21.

9. Dağ ZÖ, Dilbaz B. Impact of obesity on infertility in women. J Turk Ger Gynecol Assoc. 2015;16(2):111.

10. Filicori M, Flamigni C, Meriggiola MC, Ferrari P, Michelacci L, Campaniello E, et al. Endocrine response determines the clinical outcome of pulsatile gonadotropin-releasing hormone ovulation induction in different ovulatory disorders. J Clin Endocrinol Metab. 1991;72:965-72.

11. Hardie DG. AMPK: a key regulator of energy balance in the single cell and the whole organism. Int J Obes. 2008;32(S4):S7-S12.

12. Isakovic A, Harhaji L, Stevanovic D, Markovic Z, Sumarac-Dumanovic M, Starcevic V, Micic D, Trajkovic V. Dual antiglioma action of metformin: cell cycle arrest and mitochondria-dependent apoptosis. Cell Mol Life Sci. 2007; 64(10):1290-302

13. Kuokkanen S, Polotsky AJ, Chosich J, Bradford AP, Jasinska A, Phang T, Santoro N, Appt SE. Corpus Luteum as a novel target of weight changes that contribute to impaired female reproductive physiology and function. Systems Bio Reprod Med. 2016;62(4):227-42.

14. Li TC. Guides for practitioners. Recurrent miscarriage: principles of management. Hum Reprod. 1998;13:478-82

15. Li TC, Spuijbroek MD, Tuckerman E, Anstie B, Loxley M, Laird S. Endocrinological and endometrial factors in recurrent miscarriage. BJOG Int J Obstet Gynaecol. 2000;107(12):1471-9.

16. Liu XR, Mu HQ, Shi Q, Xiao XQ, Qi HB. The optimal duration of progesterone supplementation in pregnant women after IVF/ICSI: a meta-analysis. Reprod Biol and Endo. 2012;10(1):107.

17. Liu X, Chhipa RR, Nakano I, Dasgupta B. The AMPK Inhibitor Compound C Is a Potent AMPK-Independent Antiglioma Agent. Mol Cancer Ther. 2014;13: 596-605.

18. Prior JC. Ovarian aging and the perimenopausal transition: the paradox of endogenous ovarian hyperstimulation. Endocrine. 2005:26:297-300.

19. Russell DL, Salustri A. Extracellular matrix of the cumulus-oocyte complex. Semin Reprod Med. 2006;24:217-27.

20. Sheffel CE, Pratt BR, Ferrell WL, Inskeep EK. Induced corpora Lutea in the postpartum beef cow II Effects of Treatment with Progestogen and Gonadotropins. J Anim Sci. 1982;54:830-6.

21. Strott CA, Cargille CM, Ross GT, Lipsett MB. The short luteal phase. J Clin Endocrinol \& Metab. 1970;30(2):246-51.

22. Tang YC, Williams BR, Siegel JJ, Amon A. Identification of aneuploidyselective antiproliferation compounds. Cell. 2011;144(4):499-512.

23. Tosca L, Chabrolle C, Uzbekova S, Dupont J. Effects of metformin on bovine granulosa cells steroidogenesis: possible involvement of adenosine $5^{\prime}$ monophosphate-activated protein kinase (AMPK). Biol Reprod. 2007;76:368-78.

24. Tosca L, Crochet S, Ferré P, Foufelle F, Tesseraud S, Dupont J. AMP-activated protein kinase activation modulates progesterone secretion in granulosa cells from hen preovulatory follicles. J Endocrinol. 2006;190:85-97.

25. Tosca $L$, Froment $P$, Solnais $P$, Ferré $P$, Dupont J. Adenosine $5^{\prime}$ Monophosphate-Activated Protein Kinase Regulates Progesterone Secretion in Rat Granulosa Cells. Endocrinology. 2005;146:4500-45113.

26. Younis JS. Ovarian aging and implications for fertility female health. Minerva Endocrinol. 2012:37:41-57.

\section{Submit your next manuscript to BioMed Central and we will help you at every step:}

- We accept pre-submission inquiries

- Our selector tool helps you to find the most relevant journal

- We provide round the clock customer support

- Convenient online submission

- Thorough peer review

- Inclusion in PubMed and all major indexing services

- Maximum visibility for your research

Submit your manuscript at www.biomedcentral.com/submit

CBiomed Central 